Relations industrielles

Industrial Relations

\title{
The Psychology of Assessment Centers, edited by Duncan J. R. Jackson, Charles E. Lance and Brian J. Hoffman, New York: \\ Routledge, 2012, 360 pp., ISBN: 978-0-4158-7814-2.
}

\section{Arthur Poropat}

Volume 68, numéro 4, automne 2013

URI : https://id.erudit.org/iderudit/1023014ar

DOI : https://doi.org/10.7202/1023014ar

Aller au sommaire du numéro

Éditeur(s)

Département des relations industrielles de l’Université Laval

ISSN

0034-379X (imprimé)

1703-8138 (numérique)

Découvrir la revue

Citer ce compte rendu

Poropat, A. (2013). Compte rendu de [The Psychology of Assessment Centers, edited by Duncan J. R. Jackson, Charles E. Lance and Brian J. Hoffman, New

York: Routledge, 2012, 360 pp., ISBN: 978-0-4158-7814-2.] Relations industrielles

/ Industrial Relations, 68(4), 713-716. https://doi.org/10.7202/1023014ar

Tous droits réservés @ C Département des relations industrielles de l’Université Laval, 2013
Ce document est protégé par la loi sur le droit d'auteur. L'utilisation des services d'Érudit (y compris la reproduction) est assujettie à sa politique d'utilisation que vous pouvez consulter en ligne.

https://apropos.erudit.org/fr/usagers/politique-dutilisation/ 
constitutes an attack on a person's religion or freedom of conscience. However France forbids girls or women wearing the hijab in all public schools. Closer to home in Quebec, the government's Bill 94 attempted to restrict women's right to wear the veil when accessing government services, such as schools or hospital care.

In conclusion, Work Stress argues that prior to 1980 there was no great need to look at workplace stress and coping until globalization started to expand. The book explains many Western and non-Western attitudes toward workplace stress and its effect on people and organizations. And, as the authors hint, with the precipitous rise of globalization, the situation will only get worse.

\section{Judy Haiven}

Saint Mary's University

\section{The Psychology of Assessment Centers}

edited by Duncan J. R. Jackson, Charles E. Lance and Brian J. Hoffman, New York: Routledge, 2012, 360 pp., ISBN: 978-0-41587814-2.

For those who are new to the term, "assessment centre" is something of a misnomer, referring less to a place than a method of bringing together multiple assessments of individuals in order to determine their value for an organization. The purpose of assessment centres can vary, including selection, promotion and professional development, but the integration of multiple assessments, including behavioural ratings and cognitive and personality assessments, obtained from multiple sources such as self, peer and observer ratings, is typical. As such, few individual activities in human resource management and employment relations better encapsulate the complexity of organizations and their interaction with staff than do assessment centres. Almost the full range of issues to do with managing people can be found here, complete with conflicting views on the meaning of guid- ance and performance, along with active impression management by all parties, compounded by recognition and rewards provided amidst multifarious implicit and explicit promises and expectations, all within a context of legal and quasi-legal extra-organizational requirements. Assessment centres have it all.

The editors of this book chose to make this more manageable by deliberately adopting a measurement paradigm within an organizational psychology perspective. Considered from within this point of view, the range of authors and topics is hard to fault - indeed, Charles Lance and Brian Hoffman seem to be self-evident choices as both editors and authors. Apart from these, researchers with strong track records have been included (e.g., Filip Lievens and Winfred Arthur Jr.) along with two of the biggest names in psychological research on work performance in the last few decades, Paul Sackett and Walter Borman, who top and tail the collection. These over-performers in organizational psychology research are supported by a strong range of researchers and research-informed practitioners. Nonetheless, it would have been good to also have input from Frank Schmidt and Kevin Murphy and their colleagues, given that their views on measurement are entirely pertinent to measurement issues within assessment centres, about which more is discussed later in this review.

Sackett's Foreword contextualized the volume using an issue that Sackett himself helped to highlight (Sackett and Dreher, 1982), specifically the role of exercises and dimensions in accounting for variance in post-exercise dimension ratings (PEDRs) and overall assessment centre ratings (OARs). The editors used these components of measurement variance within assessment centre ratings to guide discussion and provide structure to the volume, after the introductory, scene-setting chapters.

The introductory chapters are generally quite informative, beginning with a useful 
summary of assessment centres by Povah and Povah, who highlighted key features and benefits as well as potential problems, although the discussion of potential for illegal discrimination was a little cursory. Highhouse and Nolan provided an intriguing account of the origins of assessment centres within German, British and American militaries, and their subsequent transition to large corporate employers. Woehr, Meriac and Bowler's overview of issues relating to measurement issues ranged from how assessment ratings are produced and integrated to provide PEDRs and/or OARs, through various applications of psychometric analysis including reliability, validity and analysis of multi-trait multi-method matrices (MTMMs). Lievens and Christiansen finished the introductory section with a summary of what they view as the core debates related to assessment centres. This chapter recapitulated the exercise-dimension-interaction discussion but placed it within wider research agendas within psychology, especially the person-situation debate within personality research.

Parts two, three, and four of the book address dimension-based, exercise-based (subsequently referred to as task-based), and interaction (referred to as mixedmodel) approaches to assessment centres. Each of these parts takes a similar structure, with theoretical conceptual issues in the first chapter, practical application in the second, and research evidence presented in the third. The boundaries between the models are fuzzy, resulting in a fair degree of overlap and conceptual repetition both between these parts and with the introductory part of the book. Yet, this had the saving grace of allowing interesting debates about the relative merits of each approach thereby extending the depth of the discussion, a feature which would, however, have been enhanced by explicit cross-referencing of ideas between different parts. Another strength of these central parts of the book are the application chapters. Although none of these attempt to provide a paintby-numbers guide, the first two (those by Jansen, and by Thoresen and Thoresen) provide sufficient detail that a competent human resource management practitioner should be able to construct a creditable assessment centre using their guidance and reference lists.

The final part of the book is a chapter by Walter Borman, who presents more of an overview of the field than a dialogue with the rest of the book. Borman argued that when compared with dimension- and taskbased models, mixed-model approaches to assessment centres are "the winner," as they contain the best from the other two approaches while extending these by including their interactions. Nonetheless, the mixed-model approach appears to have been less-frequently applied and researched, apparently because it is comparatively complicated, which is reflected by the comparatively more difficult guidance presented in the mixed-model application chapter by Hoffman.

This is generally a well-written book, at least for someone who is familiar with the terminology and conceptual landscape within which assessment centres are discussed. Novices may find some sections challenging, especially the discussion of statistical models, but the writing is reasonably lucid and the various authors usually provide clear indications of where to go for further information. Despite this, as with too many edited books the index is disappointing, with key concepts and issues left unmentioned or unevenly acknowledged within the index (as just one example, several sections of Jansen's chapter provide substantial content on specific issues that are not referenced within the index). The absence of an author index is puzzling, because despite the clear efforts at providing practical applications the book is likely to be of most use to researchers and students, for whom the tracking of authors and citations is often crucial. 
Even so, the book remains accessible to the reader. In large part, this is due to the tidy, logical, matrix-like structure, which reflects the tidy, matrix-like methodology underlying the statistical analysis of assessment centres, and this resonance of format with content makes it easier to navigate a potentially confusing topic. Yet, although this neat matrix-like structure facilitated discussion of dimensions, exercises, and their interaction, it raises questions about alternative ways in which assessment centres vary that were not systematically considered. For example, assessment centres are typically linked with reward and recognition, either by means of access to jobs or developmental opportunities. Yet the effects of varying reward and recognition are barely mentioned, despite their substantial consequences for effort and impression management, which in turn affect assessment. Likewise, where is the systematic analysis of occupations and cultural/demographic groups as further dimensions for analyzing assessment centres? Several of the authors acknowledge that gender and race have been linked with assessment centre ratings but this issue was not thoroughly addressed, despite people being one of the major sources of variance within measurement models of the type underlying the book's structure. This is no small issue, either with respect to the size of the effects cited in passing within the book, nor with respect to the consequences for non-discriminatory practice (see Bobko and Roth, 2013 for a recent review of one aspect of this).

Another important gap is that the book does not acknowledge the role of assessment centres in maintaining and distributing power and resources. This is a concern because any system of assessment that explicitly integrates multiple perspectives of multiple targets across multiple tasks and dimensions will inevitably mirror many if not all of the multiple political and social issues that industrial relations researchers (among others) routinely discuss. It is not hard to find critical perspectives on employee assessment - Tourish (2013) is just one recent example. Admittedly, the editors and authors of this volume come from a tradition (Industrial-Organizational Psychology) that often treats "performance" as a given but writers within that tradition, such as Kevin Murphy (Murphy, 2008; Murphy and Cleveland, 1991; Murphy and De Shon, 2000), have long been providing evidence for the motivated and political nature of performance, both in conception and measurement. Further, performance is self-evidently a contested construct, which almost everyone who has been through a selection process or sat on either side of a performance review can verify. A comprehensive presentation on the psychology of assessment centres would not merely discuss the measurement and prediction of performance, but also consider the role of assessment centres in helping to negotiate the concept of performance and the political outcomes for those involved.

Yet it is the clarity of the analysis provided by The Psychology of Assessment Centers that makes apparent these shortcomings, which reflect more upon the biases within Industrial-Organizational Psychology than they do upon this volume. Overall, I found this to be an enlightening and readable presentation of an important focus for research and practice within organizations. People who are interested in getting to grips with the practical and methodological underpinnings of individual assessment for organizational management would do well to engage with this book.

\section{References}

Bobko, P., and P. L. Roth. 2013. "Reviewing, Categorizing, and Analyzing the Literature on Black-White Mean Differences for Predictors of Job Performance: Verifying Some Perceptions and Updating/Correcting Others." Personnel Psychology, 66 (1), 91-126.

Murphy, K. R. 2008. "Explaining the Weak Relationship between Job Performance and Ratings of Job Performance." Industrial and Organizational Psychology, 1 (2), 148-160. 
Murphy, K. R., and J. N. Cleveland. 1991. Performance Appraisal. Boston: Allyn and Bacon.

Murphy, K. R., and R. De Shon. 2000. "Interrater Correlations Do Not Estimate the Reliability of Job Performance Ratings." Personnel Psycho/ogy, 53 (4), 873-900.

Sackett, P. R., and G. F. Dreher. 1982. "Constructs and Assessment Center Dimensions: Some Troubling Empirical Findings." Journal of Applied Psychology, 67 (4), 401-410.

Tourish, D. 2013. "'Evidence Based Management,' or 'Evidence Oriented Organizing?' A Critical Realist Perspective." Organization, 20 (2), 173 192.

\section{Arthur Poropat}

Griffith University

\section{GRH et mondialisation : nouveaux contextes, nouveaux enjeux}

sous la direction de Didier Cazal, Éric Davoine, Pierre Louart et Françoise Chevalier, Paris : Éditions Vuibert, 2011, 270 p., ISBN : 978-2-311-00309-3.

Précédé d'une introduction sur les différentes approches de la gestion internationale des ressources humaines (GIRH) qui débouche sur les questions fondamentales que posent les textes contenus dans cet ouvrage, ce volume est subdivisé en deux parties : la première traite de l'imbrication des différents contextes, c'est-à-dire de l'influence des firmes multinationales sur les pratiques locales de GRH, mais aussi, pour reprendre l'expression de Cazal, Davoine, et al. (p. 2), " du local dans le global », alors que la seconde partie aborde les nouveaux enjeux avec un chapitre final sur l'état de la recherche en GIRH et les nouvelles perspectives théoriques et méthodologiques. Le lecteur aura compris que ce volume est une compilation de différentes contributions. Bien qu'une lecture chapitre par chapitre serait préférable pour rendre compte de l'apport des différents auteurs, nous proposons, par souci d'économie d'espace, une appréciation par section, en esquissant quelques commentaires et références à certains articles représentatifs du propos et des objets de cet ouvrage.
La première partie traite de la « construction » des pratiques de GRH à l'international et de la primauté conceptuelle de la notion de culture comme déterminant sociétal du particularisme des pratiques de $\mathrm{GRH}$, compte tenu notamment de l'hégémonie des travaux pionniers de Hofstede et d'Iribarne. On évoque les limites, les excès et les dérives d'un culturalisme statique, déterministe et universaliste, prédictif des comportements et des pratiques de GRH, en nous instruisant fort adéquatement sur I'usage abusif d'une certaine notion de culture. Cazal (p. 133) dénonce également l'ethnocentrisme du concept de culture où la notion est " davantage révélatrice de la culture des chercheurs que de celle des acteurs étudiés ». À cette vision positiviste et fonctionnaliste, on oppose une conception constructiviste de la culture et des pratiques de GRH qui semble respectueuse des particularités des entreprises et des différents contextes. Ainsi, le chapitre 1 évoque l'idée de la nationalité comme " construit social » et le chapitre 4 l'hybridation des pratiques $\mathrm{GRH}$ entre les maisons mères et leurs filiales (fusion du global et du local) comme résultat des interactions entre les acteurs. Ce processus d'hybridation fait I'objet d'une lecture constructiviste pertinente de Yahiaoui comme celle du chapitre 6 où Nizet et Pichault précisent que l'usage des outils occidentaux ou africains est étroitement lié au pouvoir de certains acteurs et à certaines caractéristiques du contexte des organisations. Ils discutent aussi des voies privilégiant l'usage unique des outils occidentaux qu'ils questionnent en raison de présupposés tenaces sur l'imprévisibilité africaine. Au chapitre 7, Livian pose son regard sur la GRH embryonnaire en Chine et notamment sur la mise en œuvre de l'idée d'hybridation ou du croisement des méthodes de GRH entre la maison mère et I'entreprise locale. Ainsi, le dosage différent de cette hybridation serait davantage liée au type d'entreprise : les co-entreprises sino-étrangères sont celles qui adoptent 